\title{
Predicting College Math Success: Do High School Performance and Gender Matter? Evidence from Sultan Qaboos University in Oman
}

\author{
M. Mazharul Islam ${ }^{1} \&$ Asma Al-Ghassani ${ }^{1}$ \\ ${ }^{1}$ Department of Mathematics and Statistics, Sultan Qaboos University, Muscat, Oman \\ Correspondence: M. Mazharul Islam, Department of Mathematics and Statistics, College of Science, Sultan Qaboos \\ University, P.O. Box 36, PC 123-Muscat, Oman. E-mail: mmazhar.islam@yahoo.com; mislam@squ.edu.om
}

Received: February 4, 2015

Accepted: February 26, 2015

Online Published: March 9, 2015

doi:10.5430/ijhe.v4n2p67

URL: http://dx.doi.org/10.5430/ijhe.v4n2p67

\begin{abstract}
The objective of this study was to evaluate the performance of students of college of Science of Sultan Qaboos University (SQU) in Calculus I course, and examine the predictive validity of student's high school performance and gender for Calculus I success. The data for the study was extracted from students' database maintained by the Deanship of Admission and Registration office of SQU. The study considered a sample of 615 students who took Calculus I course during 2014 spring semester. Both descriptive and inferential statistical techniques were used for data analysis. Predictive validity of selected factors were analyzed using Hierarchical regression analysis. The analysis revealed that female students entered in SQU with a higher average high school scores than male students, and many boys with lesser high school scores than girls were succeeded in getting admission at SQU. The results indicate that female students outperformed male students in both high school and college Calculus course. About $30 \%$ of the students obtained grades lower than C in Calculus I, of which $20 \%$ failed in the course. The proportion of students with $\mathrm{F}$ grade was found to be significantly higher among male students compared to female students (28\% vs. 7\%). The analysis revealed that gender, high school math score and overall high school score are significant predictors of subsequent performance in Calculus course at college level. Thus differences among gender and high school performance should be taken into consideration during the admission process to allow for more equal opportunities to all applicants and have fairer admission decisions.
\end{abstract}

Keywords: Predictive validity, Math success, Performance, Gender, Sultan Qaboos University, Oman

\section{Introduction}

The history of higher education system in Oman is relatively short. At the time of assuming power in 1970 by His Majesty Sultan Qaboos Bin Said, the present ruler of Oman, there were only three formal school in Oman (Al-Belushi et al., 1999). Since 1970, Oman has made remarkable progress in expanding access to education, developing an Omani teaching force, and building an Omani education sector. The total population of Oman reached to a landmark of 4 million in 2014, of which 2.2 million are native Omani and the rest 1.8 million are expatriate (National Center for Statistical Information, 2015). More than $80 \%$ of the Omani men and women aged 15 and above are now literate. Oman now has over 1,000 government run schools, providing free education to its citizens. The first and the comprehensive University in Oman, the Sultan Qaboos University (SQU), named after His Majesty Sultan Qaboos Bin Said, was founded in 1986. Today, SQU is the only public University in Oman with more than 15,000 students and nine colleges including: college of Agriculture, Arts, Commerce and Economics, Education, Engineering, Law, Medicine, Nursing, Science, offering bachelor's, master's and in some colleges doctoral programs. Since its inception in 1986, the basic standard for admission at SQU has been the students' high school achievement scores and their branches of study (i.e. science or arts) at high school level. The secondary school scores are used as a criteria for selecting suitable students for admission in undergraduate level, while branches of study are used in choosing the college of study. Unlike the Universities and Colleges in North America and many other places, SQU accept students in its under graduate programs on the basis of their high school scores without testing students' readiness for higher education. Most of the Universities and Colleges in North America and elsewhere admit students on the basis of their achievement scores of admission test, or SAT (Scholastic Assessment Test) or ACT (American College test) in addition to high school scores. However, recently SQU introduced a one year foundation program to prepare the students to take up undergraduate program with a major subject of study. In addition to high school scores, the Admission and Registration (A\&R) office of SQU also emphasized on the gender balance of students in 
most colleges while admitting the students in undergraduate program.

Students entering the science based undergraduate program at SQU are required to take and pass several core courses on Mathematics, which is typical in many other institutions elsewhere. Calculus is one of these courses. The course is taught by the faculties of Mathematics and Statistics department of SQU. Calculus course is also used as the 'critical filter' to many college majors at SQU. The course provides the mathematical background and foundation for understanding higher-level science based courses (Gainen \& Willemsen, 1995). In order to proceed in a major subject, a student must obtain a minimum grade ' $\mathrm{C}$ ' in the Calculus course. Unfortunately, the course often turns deterrents in the pursuance of higher education at SQU. Although there is no comprehensive study on this issue, anecdotal information and experience indicate that a substantial proportion of the college freshmen fail to meet the minimum grade criteria of $\mathrm{C}$ and above. As a result they have to repeat the course, and their normal academic life is delayed. Some of these students ultimately have to leave the university because of their repeated poor performance in Calculus. One recent study demonstrated that the drop-out rate at SQU is close to a double digit figure and it is increasing in recent time (Al Ghanboosi and Ayedh, 2013). Among other factors, the poor performance of the freshmen in SQU might have relation with their high school performance. Weak background in mathematics courses at school level often lead to an overall poor performance in college level calculus and may contribute to performance difficulties among the freshman students. A significant body of literature suggests that the basic mathematics skill gained at high school and overall high school GPA are the best predictors of freshmen's math and overall GPA during their undergraduate studies (Hoffer et al. 1995; Camara \& Echternacht, 2000; Ma, 2000; Snyder et al., 2003; Achieve, 2004). In recent years, gender of students have emerged as an important determinant of academic success. It has been demonstrated repeatedly that, in general, girls outperform boys academically both at school and colleges throughout the world with some exception (Jackson, 1978; Fischer et al., 2013; Islam, 2014). Oman is not an exception in this regard. In a recent study, Islam (2014) observed that girls in SQU outperform boys academically.

To the best of our knowledge, there has been no study to examine how well high school grades and gender of students predict their success in Calculus at SQU. There is a need for the identification of factors that contribute to the successful completion of calculus among freshman undergraduate students of SQU. Because of growing interest and competition in higher education and growing need of highly educated citizens in Omani society, it is important to examine the effectiveness of the admission criteria of SQU to ensure that only qualified students are admitted to the university. Thus the objective of this study was to evaluate the performance of students in Calculus course, and examine the predictive validity of high school performance and gender of the students for success in Calculus course among the freshmen of SQU.

The findings of this study can be valuable in many ways. It may guide admissions personnel and decision-makers at the Ministry of Education (MoE) and SQU in the development of future admission plans and student retention programs at universities and colleges in Oman. This study is expected to bridge the research gap in studying the academic performance of students attending postsecondary institutions in Oman and thus may serves as a pilot study for future research to be conducted in this area.

\section{Literature Review}

The academic performance of a student in his or her first few college courses set his or her future achievements in college (Armstrong, 2000). Researchers observed that the good grades of first year college courses are strongly related to persistence and graduation from an institution, and entry into high-level occupations (Tinto, 1975; Baird, 1985; Pascarella \& Terenzini, 1991). However, the academic performance among the college freshmen depends on many factors including: cognitive factors (e.g., high school achievement, SAT or ACT score), non-cognitive factors (e.g., teaching and institutional quality, students' motivation and so on) and demographics (e.g., gender, ethnicity, location). These are also the selection criteria employed by most of the higher educational institutions across the globe in deciding which students are more qualified and most likely to succeed in these institutions. Traditionally, cognitive factors such as high school achievement score, SAT and ACT are widely considered as admission criteria by most of the higher education institutions in various countries. Some institutions use only the high school achievement scores, while others use both high school scores and standardized scores (SAT or ACT) to select the students (Pentages \& Creedon, 1978; Kappe \& Flier, 2012; Clercq et al., 2013).

Many studies have shown that both high school grade point averages and standardized test scores, such as the SAT or ACT, are generally significant predictors of students' success during their undergraduate studies (Noble, 1991; Barron \& Norman, 1992; Waugh et al., 1994; Wolfe \& Johnson, 1995; Bridgeman et al., 2000; Kim, 2002; Snyder et al., 2003; Cohn et al., 2004; Kuncel et al., 2005). On the other hand, a significant body of literature suggests that high school GPA is the best predictor of freshman GPA during their undergraduate studies and it has more predictive 
power than the standardized tests or any other factor (Lawlor et al., 1997; Kowarsky et al., 1998; Betts \& Morrell, 1999; Camara \& Echternacht, 2000; Tross et al., 2000; Fleming, 2002; Zheng et al., 2002; Snyder et al., 2003; Geiser and Santelices, 2007). However, some of the studies demonstrated that high school GPA has less adverse impact on admission prospects of economically disadvantaged students compared with the SAT because it is much less correlated with students' socioeconomic characteristics than standardized tests (Kowarsky et al., 1998; Geiser and Studley, 2003; Geiser and Santelices, 2007). One study concluded that much of the SAT's predictive power derives from its correlation with socioeconomic background and high school attributes (Rothstein, 2004).

Wang and Goldschmidt (2000) examined the effects of mathematics courses taken by students at the high school level and observed that it plays a prominent role in higher level mathematics achievement. In another study, Ma (2001) showed that students exposed to advanced mathematics courses at the middle and junior high school level had high mathematics achievement in subsequent academic life. Many previous studies also demonstrated that high school students who take more mathematics courses perform better in standardized tests of mathematics achievement (Gamoran, 1987; Hoffer et al., 1995; Wilhite et al., 1998). Students who took advanced courses in mathematics were found to be more prepared for college education, and received higher scores on college admissions tests (Schneider et al., 2003). Some researchers argued that rigorous high school courses help prepare students for the college learning environment and enhance their ability to succeed in higher education (Adelman, 1999; Bourquin, 1999). The more strong background in mathematics students achieved in high school, the more likely they are to earn college degrees (Adelman, 1999; Adelman, Daniel, \& Berkovits, 2003; Achieve, 2004; Adelman, 2006; Bedsworth, Colby, \& Doctor, 2006).

\section{Methods}

The data for the study come from a sample of 615 students who took Calculus I course during spring 2014 semester as freshmen entering undergraduate program in SQU. The sample consisted of students from 2009-2013 admission cohorts. The final grade on Calculus I of 615 students along with their gender, cohorts, high school math scores, overall high school scores were obtained from the student database maintained by the Deanship of Admission and Registration office of SQU. Calculus I grade was recorded on a 4 point scale using letter grade $\mathrm{A}=4, \mathrm{~A}-=3.7, \mathrm{~B}+=3.3$, $\mathrm{B}=3.0, \mathrm{~B}-=2.7, \mathrm{C}+=2.3, \mathrm{C}=2.0, \mathrm{C}-=1.7, \mathrm{D}+=1.3, \mathrm{D}-=1.0$ and $\mathrm{F}=0.0$. High school math scores and high school overall scores were recorded in percentage. High school overall scores refers to the mean percentage score over all subjects taken in the twelfth grade exams. As we do not have any information about quality characteristics of various high schools we assumed them homogeneous in term of quality and used their raw scores without standardizing (Z-scoring) them. Data was obtained from students' record as an Excel spreadsheet and then imported into SPSS for statistical analysis. It is worth mentioning here that all the 615 students took high school math course in twelfth grade. Among the 615 students, 33 students (5.4\%) withdrew from the Calculus I course. Thus, the study considered 615 cases for background analysis and 582 cases for subsequent performance analysis of Calculus I and its predictive validity.

The data analysis for this study included both descriptive and inferential statistics. Descriptive statistics were computed for all key variables. Inferential statistics techniques involved analysis of variance (ANOVA) and hierarchical regression techniques, considering college Calculus I grade point average (GPA) as the dependent variable or criterion variable and high school math score, high school overall score and gender as the predictors or independent variables. Hierarchical regression was conducted to determine the predictive validity of overall high school score, high school math score and gender on the college math (Calculus I) success. Hierarchical regression is in many ways similar to standard multiple regression, the only difference is that the independent variables are entered in the model in a hierarchical manner based on some theoretical consideration.

Hierarchical regression analysis provides the proportion of explained variance, also known as the coefficient of determination or $R^{2}$, in the criterion variable that is accounted for or explained by the predictor variables (high school score, high school math score and gender) in each model in the regression and the change in $R^{2}$ in the following model. Adjusted $R^{2}$ value is a value that takes into account the number of variables in the model and the number of observations or participants the model is based on. One can test the significance of difference of two $R^{2}$ s by the $F$-test to determine if adding an independent variable to the model helps significantly. Using hierarchical regression, one can see how most variance in the dependent variable can be explained by one or a set of independent variables, over and above that explained by an earlier variable(s). 
Table 1. Background characteristics of students

\begin{tabular}{|c|c|c|}
\hline Characteristics & Number & Percent \\
\hline \multicolumn{3}{|l|}{ Gender } \\
\hline Male & 384 & 62.4 \\
\hline Female & 231 & 37.6 \\
\hline \multicolumn{3}{|l|}{ Cohort } \\
\hline 2009 & 10 & 1.6 \\
\hline 2010 & 20 & 3.3 \\
\hline 2011 & 80 & 13.0 \\
\hline 2012 & 300 & 48.8 \\
\hline 2013 & 205 & 33.3 \\
\hline \multicolumn{3}{|l|}{ College } \\
\hline Agriculture \& Marine Science & 57 & 9.3 \\
\hline Education & 19 & 3.1 \\
\hline Engineering & 283 & 46.0 \\
\hline Science & 247 & 40.2 \\
\hline Others & 9 & 1.5 \\
\hline \multicolumn{3}{|l|}{ High school math score (in) } \\
\hline$<70$ & 54 & 8.8 \\
\hline $70-79$ & 119 & 19.3 \\
\hline $80-89$ & 228 & 37.1 \\
\hline $90-100$ & 214 & 34.8 \\
\hline Mean score $( \pm \mathrm{SD}),[\min , \max ]$ & \multicolumn{2}{|c|}{$84.4( \pm 9.5),[50,100]$} \\
\hline \multicolumn{3}{|l|}{ High school score (in \% ) } \\
\hline$<70$ & 8 & 1.3 \\
\hline $70-79$ & 14 & 2.3 \\
\hline $80-89$ & 277 & 45.0 \\
\hline $90-100$ & 316 & 51.4 \\
\hline Mean score $( \pm \mathrm{SD})[\min , \max ]$ & \multicolumn{2}{|c|}{$88.8( \pm 5.6),[54.4,97.8]$} \\
\hline
\end{tabular}

The hierarchical regression output provided three separate models with the first model only using high school score as a predictor of the college Calculus I GPA, the second model using both high school grade and high school math score as predictors of the college Calculus I GPA and third model using high school score, high school math score and gender as predictors of college Calculus I GPA. Prior to conducting hierarchical multiple linear regression analyses, an intercorrelation matrix using Pearson product moment correlations was examined to determine the extent to which each of the independent variables (overall high school score, high school math score and gender) was related to the dependent variable (GPA in Calculus I). The assumptions underlying regression were also examined to assess the appropriateness of the regression models (Mertler \& Vannatta, 2002). The assumption of homoscedasticity was examined as well.

\section{Results}

\subsection{Characteristics of Students}

Among the students who took Calculus I during spring 2014 semester, more than sixty percent $(62 \%)$ of them were male and 38\% were female (Table 1). Students were mainly from college of Engineering (46\%) and college of 
Science (40\%), constituting $86 \%$ of the total students. Around $9 \%$ students occurred from college of Agriculture and Marine Science, $3 \%$ from college of Education and a small proportion of $1.5 \%$ from other colleges. Most of the students (82\%) were from recent cohorts of 2012 and 2013. The high school Math scores of the students ranges from $50 \%$ to $100 \%$ with an average of $84 \%( \pm 9.5)$. Around one-third $(35 \%)$ of the students had $90 \%$ and above marks in high school Math, while 37\% students had $80 \%$ to $89 \%$ marks and $9 \%$ had below $70 \%$ marks in high school Math (Table 1). The overall high school scores of the sample students ranges from $54.4 \%$ to $97.8 \%$ with an average of $88.8 \%( \pm 5.6)$. Around $96 \%$ of the students had overall high school scores $80 \%$ and above, and $4 \%$ students had below $80 \%$ marks.

There is a sharp difference in high school Math and overall high school scores between male and female students when they entered in SQU. Female students entered in SQU with a higher average of high school math score as well as overall high school score. For example, among the sample students, female had an average high school score of $93.0 \%( \pm 5.45)$, while male students had an average score of $86.3 \%( \pm 2.14)$, and the difference is statistically significant $(\mathrm{t}=18.03, \mathrm{p}<0.001)$ (Table 2). The high school scores of male students ranges from $54 \%$ to $96 \%$, while for female students it ranges from $80 \%$ to $98 \%$. High school math score also follow similar pattern across the gender of the students.

Table 2. Means and Standard Deviations of high school math score and high school score by gender

\begin{tabular}{|c|c|c|c|}
\hline \multirow[t]{2}{*}{ High school performance } & \multicolumn{2}{|c|}{ Gender } & \multirow{2}{*}{$\begin{array}{l}\text { Test of } \\
\text { significance } \dagger\end{array}$} \\
\hline & Male & Female & \\
\hline Math score & $( \pm 5.12)$ & $90.89 \quad( \pm 9.39)$ & $\mathrm{t}=15.50, \mathrm{p}<0.001$ \\
\hline Overall score & $( \pm 2.14)$ & $( \pm 5.45)$ & $\mathrm{t}=18.03, \mathrm{p}<0.001$ \\
\hline
\end{tabular}

$\dagger$ Test of significance are based on t-test, comparing mean scores between male and female students

A summary of the results of the analysis of variance (ANOVA), presented in Table 3, also confirm a significant difference in high school score and high school math score by gender. Female students had higher scores in high school and high school math compared to male students. The size of the effects of gender on high school math and overall high school score, measured by eta-squared $\left(\eta^{2}=\right.$ between SS/total SS), indicate that gender explained $28.6 \%$ variation in high school math score and $4.2 \%$ in overall high school score.

Table 3. Analysis of variance (ANOVA) summary for GPA in Calculus I, high school math score and high school score by gender

\begin{tabular}{llccccc}
\hline & Sources of variations & Sum of Squares & df & Mean Square & F & Sig. \\
\hline \multirow{3}{*}{ GPA in Calculus I } & Between Groups & 163.986 & 1 & 163.986 & 134.893 & .000 \\
& Within Groups & 705.091 & 580 & 1.216 & & \\
& Total & 869.077 & 581 & & & \\
\hline \multirow{3}{*}{ High School Math Score } & Between Groups & 14522.867 & 1 & 14522.867 & 232.475 & .000 \\
& Within Groups & 36232.930 & 580 & 62.471 & & \\
& Total & 50755.797 & 581 & & & \\
\hline \multirow{3}{*}{ High School Score } & Between Groups & 66925.375 & 1 & 66925.375 & 25.375 & .000 \\
& Within Groups & 1529744.319 & 580 & 2637.490 & & \\
& Total & 1596669.693 & 581 & & & \\
\hline
\end{tabular}

Figures $1 \mathrm{a}$ and $1 \mathrm{~b}$ illustrate the cumulative distribution of entrance scores in high school Math and overall scores for male and female students in our sample. The cumulative distribution of male scores lies above the distribution for females indicating the existence of a gender gap and lower average scores among male students than females. The figures also indicate that the female students entered in SQU with high school scores $86 \%$ and above, while for male students it was from $54 \%$ and above. 


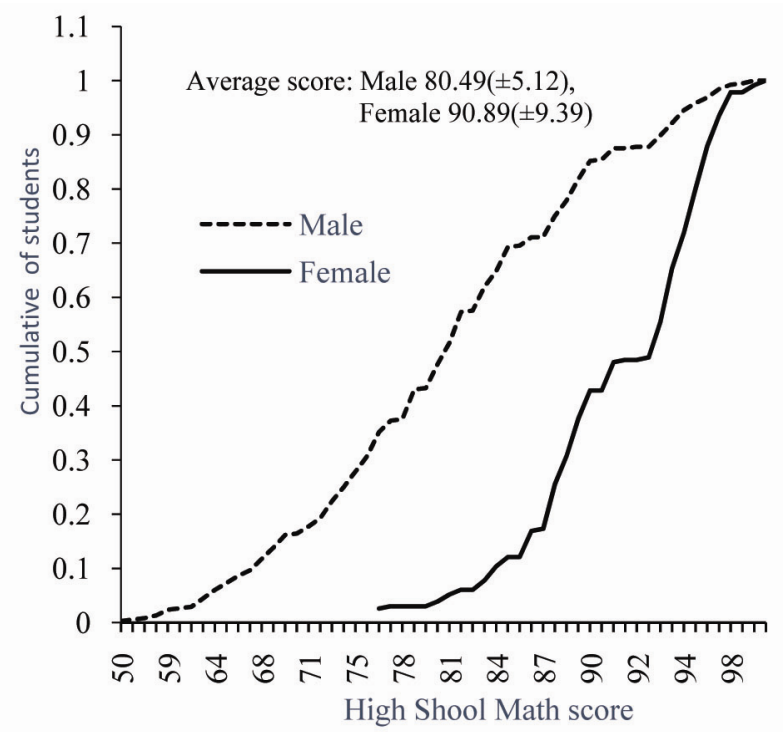

Figure 1a. Cumulative percentage of students according to high school math score and gender

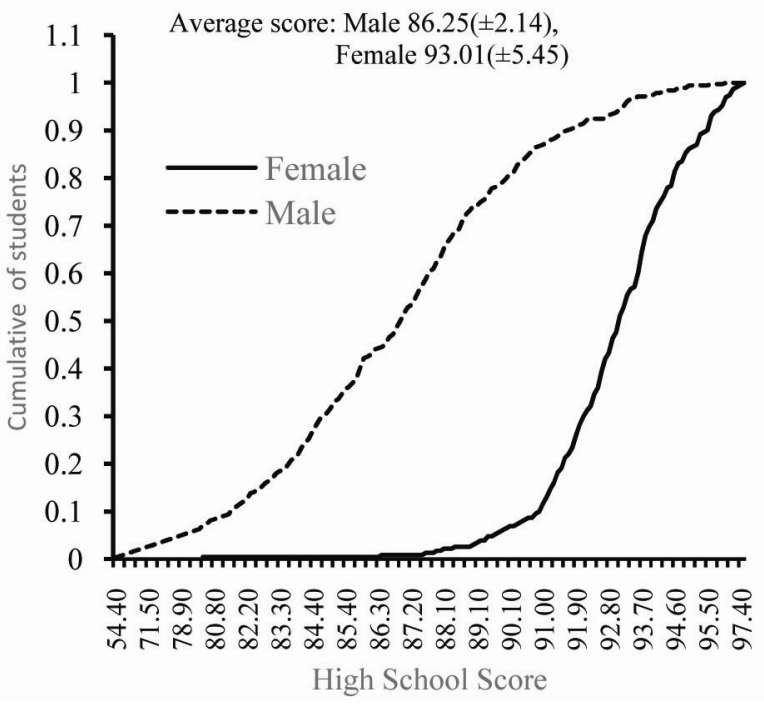

Figure 1b. Cumulative percentage of students according to high school score and gender

\subsection{Performance in Calculus I and Its Differentials}

Students' performance in Calculus I were measured by letter grade and the grade point average (GPA) in a 4-point scale. Table 4 presents the distribution of students according to their performance in Calculus I by gender. Overall, $12.7 \%$ of the students obtained grade $\mathrm{A}$ or $\mathrm{A}-, 27.5 \%$ grade $\mathrm{B}+, \mathrm{B}$ or $\mathrm{B}-, 29.4 \%$ grade $\mathrm{C}+, \mathrm{C}$ or $\mathrm{C}$-, and $10.2 \%$ students obtained grade D+ or D in Calculus I. One in every five (20.2\%) students failed (obtained grade F) in the course. 
Table 4. Percentage distribution of students according to grade in calculus and gender

\begin{tabular}{ccccc}
\hline & & \multicolumn{2}{c}{ Gender } & Total \\
\cline { 3 - 4 } Letter Grade & Grade point (4 .0 scale) & Female & Male & \\
\hline A & 4.0 & 15.2 & 2.9 & 7.5 \\
A- & 3.7 & 9.5 & 2.6 & 5.2 \\
B+ & 3.3 & 20.8 & 3.9 & 10.2 \\
B & 3.0 & 13.9 & 7.3 & 9.8 \\
B- & 2.7 & 7.4 & 7.6 & 7.5 \\
C+ & 2.3 & 11.3 & 13.3 & 12.5 \\
C & 2.0 & 5.2 & 11.7 & 9.3 \\
C- & 1.7 & 5.2 & 9.1 & 7.6 \\
D+ & 1.3 & 2.2 & 8.3 & 6.0 \\
D & 1.0 & 2.2 & 5.5 & 4.2 \\
F & 0.0 & 7.4 & 27.9 & 20.2 \\
\hline
\end{tabular}

There is sharp difference between male and female students' performance in Calculus I. Female students performed better than male students. For example, $24.7 \%$ of the female students obtained grade A or A- compared to $5.5 \%$ of the male students. On the other hand, every 3 out of 7 (43\%) male students obtained grade less than C compared to 1 in 9 female students (12\%). Male students were more likely to fail than females ( $28 \%$ vs. $7 \%)$.

Results of the analysis of variance (ANOVA) (Table 3) also indicate that there is a significant difference in college Calculus GPA by gender. Female students had higher GPA in Calculus I compared to male students. The size of the effects of gender on GPA in Calculus I as measured by eta-squared $\left(\eta^{2}=\right.$ between SS/total SS) indicate that gender explained $18.8 \%$ variation in GPA of Calculus I.

Table 5. Differentials of performance in Calculus I by selected characteristics of students

\begin{tabular}{lll}
\hline Characteristics & $\begin{array}{l}\text { GPA in Calculus } \\
\text { Mean }( \pm \text { SD })\end{array}$ & F-ratio, p-value \\
\hline Total & $2.16( \pm 1.22)$ & $134.89, \mathrm{p}<0.001$ \\
Gender & $1.74( \pm 1.16)$ & \\
$\quad$ Male & $2.83( \pm 0.99)$ & $39.36, \mathrm{p}<0.001$ \\
Female & & \\
Cohort & $1.91( \pm 1.22)$ & \\
2009 & $1.19( \pm 1.02)$ & \\
2010 & $1.70( \pm 1.06)$ & \\
2011 & $1.82( \pm 1.17)$ & $4.93, \mathrm{p}<0.001$ \\
2012 & $2.94( \pm 0.96)$ & \\
2013 & & \\
College & $1.60( \pm 1.17)$ & \\
Agriculture \& Marine Science & $2.14( \pm 1.36)$ & \\
Education & $2.35( \pm 1.22)$ & \\
Engineering & $2.06( \pm 1.18)$ & \\
Science & $2.15( \pm 1.38)$ &
\end{tabular}


High school math score

$<70$

70-79

80-89

90-100

High school score

$<70$

70-79

80-89

90-100
64.02, $\mathrm{p}<0.001$

$1.18( \pm 0.97)$

$1.39( \pm 1.02)$

$2.87( \pm 1.12)$

$2.78( \pm 1.04)$

$70.54, \mathrm{p}<0.001$
$0.67( \pm 0.76)$

$1.65( \pm 1.22)$

$1.62( \pm 1.07)$

$2.76( \pm 1.02)$

Note: Analysis was done excluding 33 students who withdrew from the course

Table 5 shows the differential analysis of the GPA in Calculus I by selected characteristics of students. As mentioned earlier, gender of the students shows significant differential effect on GPA in Calculus I. Female students performed better than male students. Cohorts of the students also shows significant differential effect on GPA in Calculus I. Recent cohort performed better than their older counterparts. Performance in Calculus vary significantly with the college of study of the students. Students from college of Agriculture and Marine Science showed lowest level of performance (GPA 1.60) followed by students from college of Science (GPA 2.06). Students from college of Engineering showed the best performance (GPA 2.35) than any other college. As expected, high school math score and high school score showed significant positive association with the performance in Calculus course. For example, the overall GPA in Calculus I was 1.18 among the students with high school math score less than 70 compared with GPA 2.87 among the students with high school score 90-100.

\subsection{Predicting College Math (Calculus I) Success}

The predictive validity of high school math and overall performance and gender in explaining college math (Calculus I) success was evaluated using correlation analysis followed by hierarchical multiple linear regression analyses. Table 6 presents the zero order correlation coefficient between GPA in Calculus I and overall high school score, high school math score and gender as well as the inter-correlation between predictors i.e. overall high school score, high school math score and gender of students. The results indicate that all the correlation coefficients were found positive and significant at 0.01 level. High school score, high school math score and gender of student have moderate positive correlation with GPA in Calculus I. The correlation coefficients between overall high school score and GPA in Calculus I, and high school math score and GPA in Calculus I were very close ( $\mathrm{r}=0.506$ and $\mathrm{r}=0.501$ respectively). This indicate that both high school score and high school math score are equally important in predicting college GPA in Calculus I. It should be noted that overall high school score and high school math score had the highest intercorrelation coefficient $(r=0.635)$ followed by overall high school score and gender $(r=0.603)$. The amount of variance $\left(\mathrm{r}^{2}\right)$ that these four variables shared ranged from $19 \%$ to $40 \%$. Although these variables were not perfectly correlated, they were moderately related to each other, with the average correlation being 0.54. Gall et al. (2003) argued that, since many factors influence the behavior patterns and personal characteristics in educational research, correlations in the range of .20 to .40 might be all that one should expect to find in the relationships between variables of study.

Table 6. Zero-Order Correlations for GPA in Calculus, gender, high school math score and high school total score

\begin{tabular}{lcccc}
\hline & High School Math Score & $\begin{array}{c}\text { High School } \\
\text { Score }\end{array}$ & Gender & GPA in Calculus \\
\hline High School Math Score & 1 & $0.635^{* *}$ & $0.535^{* *}$ & $0.501^{* *}$ \\
High School Score & $0.635^{* *}$ & 1 & $0.603^{* *}$ & $0.506^{* *}$ \\
Gender of Students & $0.535^{* *}$ & $0.603^{* *}$ & 1 & $0.434^{* *}$ \\
GPA in Calculus & $0.501^{* *}$ & $0.506^{* *}$ & $0.434^{* *}$ & 1 \\
\hline
\end{tabular}

** Correlation is significant at the 0.01 level (2-tailed).

Table 7 and Table 8 present the results from the hierarchical regression analysis. Three models were fitted. Model 1 considered overall high school score as predictor of college Calculus I GPA. Model 2 considered both overall high 
school score and high school math score as predictors, while Model 3 considered overall high school score, high school math score and gender as predictors of college Calculus I GPA. The changes in $\mathrm{R}^{2}$ (coefficient of determination) in Model 2 and Model 3 were appraised to see if addition of variables provided incremental information for the prediction of college Calculus I GPA.

Table 7. Results of regression analysis of GPA of Calculus I

\begin{tabular}{|c|c|c|c|c|c|c|}
\hline \multirow{3}{*}{ Model } & \multirow{3}{*}{ Independent variable } & \multirow{2}{*}{\multicolumn{2}{|c|}{$\begin{array}{c}\text { Unstandardized } \\
\text { Coefficients }\end{array}$}} & \multirow{3}{*}{$\mathrm{t}$} & \multicolumn{2}{|c|}{ Collinearity Statistics } \\
\hline & & & & & \multirow{2}{*}{ Tolerance level } & \multirow[t]{2}{*}{ VIF } \\
\hline & & $\mathrm{B}$ & St. error of B & & & \\
\hline 1 & High School Score & 0.115 & 0.008 & $14.127 * *$ & & \\
\hline \multirow[t]{2}{*}{2} & High School Score & 0.071 & 0.010 & $7.049 * *$ & 0.596 & 1.678 \\
\hline & High School math score & 0.039 & 0.006 & $6.719^{* *}$ & 0.596 & 1.678 \\
\hline \multirow[t]{3}{*}{3} & High School Score & 0.057 & 0.011 & $5.224 * *$ & 0.499 & 2.003 \\
\hline & High School math score & 0.035 & 0.006 & $5.784 * *$ & 0.560 & 1.785 \\
\hline & Gender of students & 0.351 & 0.111 & $3.156^{* *}$ & 0.597 & 1.674 \\
\hline
\end{tabular}

Model fit and variance explained were examined. Data were first checked for possible violations of the assumptions. A power analysis at an alpha level of .01 for a hierarchical regression analysis with one predictor in the Model 1, two predictors in Model 2 and three predictors in Model 3 indicated that the sample size $(\mathrm{N}=582)$ was sufficient for a desired power level of 0.95 . The standardized predicted residual statistics $(\mathrm{M}=0, \mathrm{SD}=1.00$, Min= $-3.10, \mathrm{Max}=2.37)$ indicated that the assumption of linearity has been met. Although, there was moderate correlation between predictors, the high tolerance levels $(>0.50)$ and low VIF (variance inflation factors) $(<3)$ indicated that multicollinearity was not an issue.

Results from Model 1, as shown in Table 7 and Table 8, indicate that the overall high school performance is a significant predictor of college Calculus I success $(F(1,580)=199.57, \mathrm{p}<0.01)$. The and adjusted suggest that $26 \%$ of the variance in the college Calculus I GPA is accounted for by high school overall performance scores. Regression coefficients are another indicator of the relative strength of the predictor variables. They may be interpreted as number of points that a dependent variable (College Calculus I GPA) changes for a unit change in a predictor variable (high school score), all other factors were held constant. According to Model 1 results, college Calculus I GPA increased by 0.12 points for every unit increase in high school score.

Results from Model 2 in Table 8 show that adding high school math score variable to the model with high school overall score resulted in an increment of,$($ change $=0.054, F(2,579)=129.952, \mathrm{p}<0.01)$, indicating that the students' high school math score is a significant predictor of college Calculus I GPA in addition to overall high school performance and it added 5.4\% to the variance in students' college Calculus I GPA. According to Model 2 results, college Calculus I GPA increases by 0.04 points for every unit increase in high school math score (Table 7). When combined, high school score and high school math score accounted for $31 \%$ of the variance in the college Calculus I GPA as seen in Table 8.

Table 8. Model Summary

\begin{tabular}{cccccccccc}
\hline & & \multicolumn{3}{c}{ Adjusted } & & \multicolumn{4}{c}{ Change Statistics } \\
\cline { 7 - 10 } Model & $R$ & $R^{2}$ & $R^{2}$ & Std. Error of the Estimate & $R^{2}$ Change & F Change & df1 & df2 & Sig. F Change \\
\hline 1 & .506 & .256 & .255 & 1.05585 & 0.256 & 199.566 & 1 & 580 & .000 \\
2 & $.557^{\mathrm{a}}$ & .310 & .307 & 1.01782 & 0.054 & 129.952 & 2 & 579 & .000 \\
3 & $.567^{\mathrm{a}}$ & .322 & .318 & 1.01004 & 0.012 & 91.297 & 3 & 578 & .000
\end{tabular}

According to the Model 3 results, the addition of gender of the students as a predictor in Model 3 in addition to high school score and high school math score made a statistically significant contribution in explaining variation in college Calculus I GPA. Gender of the students added $1.2 \%$ to the variance in students' college Calculus I GPA. Model 3 results also indicate that all the three predictors i.e. high school score, high school math score and gender are significant determinants of college Calculus success. The three predictors together accounted for $32 \%$ of the variance in the college Calculus I GPA (Table 8). 


\section{Discussion}

This study analysed students' performance in college Calculus I course and examined the predictive validity of overall high school performance, high school math performance and gender of the students for Calculus I success. The data for the study come from a sample of 615 students who took Calculus I course during spring 2014 semester as freshmen entering undergraduate program in SQU. Among the 615 students, $62 \%$ were male and $38 \%$ were female. Most of the students (86\%) were from college of Engineering (46\%) and college of Science (40\%). The descriptive analysis revealed that female students entered in SQU with a significantly higher average score in both high school math and overall high school scores than male students. For example, among our sampled students, the high school scores of male students ranges from $54 \%$ to $96 \%$ with an average of $86 \%$, while for female students it ranges from $80 \%$ to $98 \%$ with an average of $93 \%$. This indicates that many boys with lesser scores than girls were succeeded in getting admission in SQU. It seems SQU is following a gender balance policy with 50:50 ratio of male female students while admitting them. This is also evident from the male-female ratio of enrolled students in SQU over the decades.

In recent time, it has been demonstrated repeatedly that girls in general are outperforming boys all over the World (Azen et al., 2002; Chambers and Schreiber, 2004; Van Houtte, 2004; Islam, 2014). This is also true for Oman. Thus, there are more eligible girls with higher percentage of high school marks than boys to be admitted in SQU and perhaps to maintain 50:50 ratio of male-female students, the Admission and Registration (A\&R) office of SQU are admitting some male students with lower school performance than female students. This admission policy might have far reaching impact on academic performance of students in SQU and their retention. The consistent better performance of female students than males in SQU may be partly related to the gender balance admission process.

This study demonstrates significant difference between male and female students' performance in college Calculus I. Female students had higher mean GPA (2.83) in Calculus I than male students (1.74). The proportion of students with letter grade $\mathrm{A}$ in Calculus I was found to be $25 \%$ among female students compared to $6 \%$ among male students. The descriptive analysis of GPA in Calculus I indicates that about 30\% of the students obtained lower than C grade, of which $20 \%$ failed in the course. As mentioned earlier, female students outperformed male students in college Calculus I. The proportion of students with lower than $\mathrm{C}$ grade varies significantly among male and female students. About $43 \%$ of the male students obtained less than $\mathrm{C}$ grade compared to $12 \%$ of the female students. The proportion of students with $\mathrm{F}$ grade also significantly higher among male students than female students (21\% vs. $5 \%)$. Students with grade less than $\mathrm{C}$ are either in the risk of dropout from the university or remain on probation which lengthen their academic life. Early college leaving or lengthening academic life is often associated with negative consequences for students, their families, and university administration. It can incur unrealized cost for families and for the university. The cost of dropping out at SQU in Oman has special significance, because SQU provides not only the free education but financial aid and free lunch for all male students and free accommodation and meals for female students. A student leaving university without having completed her/his study may also be exposed to various psycho-social problems.

The differential analysis of the GPA in Calculus I shows significant differential effect of gender, cohort, college of study, high school math score and overall high school score on college Calculus I performance. Recent cohort performed better than their older counterparts. Students from college of Engineering showed the best performance than any other college. Gender, high school math score and overall high school score showed significant positive association with the performance in Calculus course.

The hierarchical regression analysis also confirm the predictive validity of high school score, high school math score and gender in explaining the success of college Calculus course. Together these three variables explain $32 \%$ of the variance in the college Calculus I performance indicating their importance as predictors of the undergraduate courses. The findings of this study suggest that students with high scores on these two variables are likely to do well in entry level Calculus course. It implies that students with better performance in pre-college period also performed better in university.

The findings of this study correspond with many studies which found that high school GPA and high school math GPA are generally significant predictors of students' academic performance during their undergraduate studies in college (Moffat, 1993; Bridgeman et al., 2000; Kim, 2002; Snyder et al., 2003; Kuncel et al., 2007). Many researchers have further discussed that high school GPA more accurately predicts academic success in colleges than any other factors (Peltier et al., 1999; Camara \& Echternacht, 2000; Fleming, 2002; Zheng et al., 2002; Hoffman, 2005) and that standardized test scores such as SAT or ACT add little to prediction equations beyond high school GPA (Cowen \& Fiori, 1991; Myers \& Pyles, 1992 Moffatt, 1993). 
This study is not free from limitations. First, as the study was confined to success of only one college math course, the results may not necessarily be generalized as the overall success of the freshmen undergraduate students of SQU. Second, this study focused on a limited number of potential student variables affecting performance at university. Institutional, socio-economic, motivational, and environmental variables that play important role in the prediction of college success were not considered. Third, the high school scores of various high schools attended by the students may not be comparable because of their varying quality characteristics such as some schools are more generous with grading while others are more or less stringent. This might have some confounding effects on the predictive validity of the high school scores. Pike and Saupe (2002) showed that inclusion of high school quality in the model increase the predictive accuracy of the first-year grade substantially. The issue warrants more in depth research. However, in Oman all the schools follow same curriculum imposed by the Ministry of Education (MoE) and the quality of education of these schools are likely to be similar due to strong monitoring system of MoE. Due to lack of information about the quality characteristics of various schools attended by the students, we assumed that schools were homogeneous and analyzed the predictive validity of various high school scores without standardizing (z-scoring) them. Despite all these limitations, this study findings have important practical implications.

\section{Conclusion}

The findings of this study suggest that admission personnel should give more attention not only to overall high school score but also to high school math score, particularly for admission into science based colleges in SQU, because these two predictor variables have higher correlation coefficients with college outcome variable and have greater predictive power of college success in Calculus course. Since students with low high school performance tend to have lower GPA in college Calculus, the minimum admission level of high school score should be increased, particularly for male students, to improve the GPA level of collage Calculus as well as reduce the dropout rate and failure rate. A minimum admission level of $80 \%$ marks in high school final exam, irrespective of gender, could be implemented. Differences among gender and high school performance should also be taken into consideration during the admission process to allow for more equal opportunities to all applicants and have fairer admission decisions.

The findings of this study also suggest the necessity of special educational support programs for students who were admitted with low high school performance records. Possible special educational support programs could include special care, tutorial classes, guidance on study skills and other basic academic skills. Giving the fact that a great amount of variance in the criteria variable is unexplained by the predictor variables in this study, there is room for more research to study the unexplained portion of academic performance. Admission committees can admit students based on other factors. These factors could include an admission test, motivation, quality of high school and interest of students. This investigation is merely an attempt to offer insight into the possible need for further research in this area. As such, the results are by no means to be considered definitive. While not identifying all the reasons, these findings give a basis for increased interaction and discussion among high schools that prepare future students and the higher education professionals.

\section{Acknowledgement}

The authors would like to thank the Statistics and Technical Support department of Deanship of Admission and Registration office of SQU for providing relevant data for this study. Special thanks goes to Mr. Khamis Al-Abri and Mr. Haitham Al-Nahwi for their continuous support and prompt response in providing us with the required data. We express our gratitude to two anonymous reviewers and the editor of the International Journal of Higher Education for their valuable comments and suggestions that improve the quality of the paper to a great extent.

\section{References}

Achieve, Inc. (2004). American Diploma Project: Creating a high school diploma that counts. Retrieved January 23, 2013, from http://www.achieve.org.

Adelman, C. (1999). Answers in the tool box: Academic intensity, attendance patterns, and bachelor's degree attainment. Washington, DC: U.S. Department of Education, Office of Educational Research and Improvement.

Adelman, C. (2006). The toolbox revisited: Paths to degree completion from high school through college. Washington, DC: U.S. Department of Education. Retrieved from http://www2.ed.gov/rschstat/research/pubs/toolboxrevisit/toolbox.pdf

Adelman, C., Daniel, B., \& Berkovits, I. (2003, September). Postsecondary attainment, attendance, curriculum, and performance: Selected results from the NELS:88/2000 postsecondary education transcript study (PETS), 2000. 
Al Ghanboosi, S. S., \& Ayedh, A.A. A. (2013). Student Dropout Trends at Sultan Qaboos University and Kuwait University: 2000-2011. College Student Journal 47, 499-506.

Al-Belushi, S., Al-Adawi, S., \& Al-Ketani, S. (1999). Education reform in the Sultanate of Oman. Unpublished mimeograph. Muscat: Ministry of Education.

Armstrong, W. B. (2000). The association among student success in courses, placement test scores, student background data, and instructor grading practices. Community College Journal of Research and Practice 24(8), 681-695. http://dx.doi.org/10.1080/10668920050140837

Azen, R., Bronner, S., \& Gafni, N. (2002). Examination of gender bias in university admissions. Applied Measurement in Education 15, 75-94. http://dx.doi.org/10.1207/S15324818AME1501_05

Baird, L. L. (1985). Do grades and tests predict adult accomplishment? Research in Higher Education, 23, 3-85. http://dx.doi.org/10.1007/BF00974070

Barron, J., \& Norman, M. F. (1992). SATS, achievement tests, and high-school class rank as predictors of college performance. Educational and Psychological Measurement 52(4), 1047-1055. http://dx.doi.org/10.1177/0013164492052004029

Bedsworth, W., Colby, S., \& Doctor, J. (2006). Reclaiming the American dream. Boston, MA: The Bridgespan Group. Retrieved from http://www.ezsozcj.givewell.net/files/Cause4/Sponsors for Educational Opportunity (SEO)/13-2578670 Cause ReclaimingtheAmericanDreamWhitePaper.pdf

Bender, D. S., \& Garner, J. K. (2010). Using the LASSI to Predict First Year College Achievement: Is a Gender-Specific Approach Necessary? Paper presented at the meeting of the American Educational Association, Denver, CO, Apr 30-May 4, 2010.

Betts, J. R., \& Morrell, D. (1999). The determinants of undergraduate grade point average. Journal of Human Resources 34(2), 268-293. http://dx.doi.org/10.2307/146346

Bourquin, S. D. (1999). The relationship among math anxiety, math self-efficacy, gender, and math achievement among college students at an open admissions commuter institution. Dissertation Abstracts International, Section A. Humanities and Social Sciences 60(3-A), 0679.

Bridgeman, B., McCamley-Jenkins, L., \& Ervin, N. (2000). Predictions of freshman grade point average from the revised and recentered SAT I: Reasoning Test (College Board Rep. No. 2000-1). New York: College Entrance Examination Board.

Camara, W. J., \& Echternacht, G. (2000). The SAT[R] I and High School Grades: Utility in Predicting Success in College. (Report No. CB-RN-10). New York, NY: College Entrance Examination Board.

Chambers, E.A., \& Schreiber, J.B. (2004). Girl's academic achievement: Varying associations of extracurricular activities. Gender and Education 16(3), 327-346. http://dx.doi.org/10.1080/09540250042000251470

Clercq, M. D., Galand, B., Dupont, S., \& Frenay, M. (2013). Achievement among first-year university students: an integrated and contextualized approach. European Journal of Psychology of Education 28(3), 641-662. http://dx.doi.org/10.1007/s10212-012-0133-6

Cohn, E., Cohn, S., Balch, D., \& Bradley, J. (2004). Determinants of undergraduate GPAs: SAT scores, high-school GPA and high-school rank. Economics of Education Review 23, 577-586. http://dx.doi.org/10.1016/j.econedurev.2004.01.001

Cowen, S., \& Fiori, S. J. (1991). Appropriateness of the SAT in selecting students for admission to California State University, Hayward. Paper presented at the annual meeting of the California Educational Research Association, San Diego, CA.

First-Year Grades. Research in Higher Education 43(2), 187-202.

Fischer, F., Schult, J., \& Hell, B. (2013). Sex differences in secondary school success: why female students perform better. European Journal of Psychology of Education 28(2), 529-543. http://dx.doi.org/10.1007/s10212-012-0127-4

Fleming, J. (2002). Who will succeed in college? When the SAT predicts Black students' performance. Review of Higher Education 25(3), 281-296. http://dx.doi.org/10.1353/rhe.2002.0010

Gainen, J., \& Willemsen, E. W. (1995). Fostering student success in quantitative gateway courses. New Directions for Teaching and Learning (Vol. 61). San Francisco: Jossey Bass. 
Gall, M. D., Borg, W. R., \& Gall, J. P. (2003). Educational research: An introduction (7 ${ }^{\text {th }}$ ed.). White Plains, New York: Longman.

Gamoran, A. (1987). The stratification of high school learning opportunities. Sociology of Education 60, 135 -155. http://dx.doi.org/10.2307/2112271

Geiser, S., \& Santelices, M. V. (2007). Validity of high-school grades in predicting student success beyond the freshman year: High-school record vs. standardized tests as indicators of four-year college outcomes. University of California, Berkeley.

Geiser, S., \& Studley, R. (2002). UC and the SAT: Predictive validity and differential impact of the SAT I and SAT II at the University of California. Educational Assessment 8(1), 1-26. http://dx.doi.org/10.1207/S15326977EA0801_01

Hoffer, T. B., Rasinski, K. A., \& Moore, W. (1995). Social background differences in high school mathematics and science course taking and achievement (NCES Report No. 95-206). Washington, DC: National Center for Educational Statistics.

Hoffman, J. L., \& Lowitzki, K. E. (2005). Predicting college success with high school grades and test scores: Limitations for minority students. The Review of Higher Education 28(4), 455-474. http://dx.doi.org/10.1353/rhe.2005.0042

Islam, M.M. (2014). Factors Influencing the Academic Performance of Undergraduate Students in Sultan Qaboos University in Oman. Journal of Emerging Trends in Educational Research and Policy Studies 5(4), 396-404.

Jackson, R. (1978). Correlations of SAT Scores with High School Record (Research Report No. ED148871). Retrieved from Eric website:http://www.eric.ed.gov/ERICWebPortal/search/detailmini.jsp

Kappe, R., \& Flier, H.V.D. (2012). Predicting academic success in higher education: what's more important than being smart? European Journal of Psychology of Education 27(4), 605-619. http://dx.doi.org/10.1007/s10212-011-0099-9

Kim, M. M. (2002). Historically Black vs. White institutions: Academic development among Black students. Review of Higher Education 25(4), 385-407. http://dx.doi.org/10.1353/rhe.2002.0019

Kowarsky, J., Clatfelter, D., \& Widaman, K. (1998). Predicting university grade-point average in a class of University of California freshmen: An assessment of the validity of GPA and test scores as indicators of future academic performance. Institutional research paper. Oakland, CA: University of California Office of the President.

Kuncel, N. R., Credé, M., \& Thomas, L. L. (2007). A comprehensive meta-analysis of the predictive validity of the Graduate Management Admission Test (GMAT) and undergraduate grade point average (UGPA). Academy of Management Learning and Education 6, 51-68. http://dx.doi.org/10.5465/AMLE.2007.24401702

Kuncel, N. R., Credé, M., Thomas, L. L., Seiler, S. N., Klieger, D. M., \& Woo, S. E. (2005).A meta-analysis of the Pharmacy College Admission Test (PCAT) and grade predictors of pharmacy student success. American Journal of Pharmaceutical Education 69, 339-347. http://dx.doi.org/10.5688/aj690351

Lawlor, S., Richman, S., \& Richman, C. L. (1997). The Validity of Using the SAT as a Criterion for Black and White Students' Admission to College. College Student Journal 31, 507-515.

Ma, X. (2000). A longitudinal assessment of antecedent course work in mathematics and subsequent mathematical attainment, The Journal of Educational Research 94 (1), 16-28. http://dx.doi.org/10.1080/00220670009598739

Mertler, C. A., \& Vannatta, R. A. (2002). Advanced and Multivariate Statistical Methods (2nd ed.). Los Angeles, CA: Pyrczak Publishing.

Moffat, G. K. (1993). The validity of the SAT as a predictor of grade point average for nontraditional college students. Paper presented at the annual meeting of the Eastern Educational Research Association, Clearwater Beach, FL. ERIC Document Reproduction Service No. ED 356252.

Myers, R. S., \& Pyles, M. R. (1992). Relationships among high school grades, ACT test scores, and college grades. Paper presented at the annual meeting of the Mid-South Educational Research Association, Knoxville, TN. ERIC Document Reproduction Service No. ED 353 317. National Council of Teachers of Mathematics.

Noble, J. P. (1991). Predicting college grades from ACT assessment scores and high school course work and grade information (Rep. No. ACT-RR-91-3). Iowa City, IA: American College Testing Program. 
National Centre for Statistical Information (NCSI) (2015). Statistical Year Book 2014, Ministry of National Economy, Muscat, Oman.

Pascarella, E. T., \& Terenzini, P. T. (1991). How College Affects Students: Findings and Insights from Twenty Years of Research. San Francisco: Jossey-Bass.

Peltier, G. L., Laden, R., \& Matranga, M. (1999). Student Persistence in College: A review of Research. Journal of Student Retention, 1(4), 357-375.

Pentages, T. J., \& Creedon, C. F. (1978). Studies of college attrition: 1950-1975. Review of Educational Research, 48, 49-101.

Pike, G.R. \& Saupe, J.L. (2002). Does High School Matter? An Analysis of Three Methods of Predicting

Rothstein, J. (2004). College performance predictions and the SAT. Journal of Econometrics 121, 297-317. http://dx.doi.org/10.1016/j.jeconom.2003.10.003

Schneider, B. L., Kirst, M., \& Hess, F. M. (2003). Strategies for success: High school and beyond. Brookings Papers on Education Policy 6, 55-93. http://dx.doi.org/10.1353/pep.2003.0022

Snyder, V., Hackett, R. K., Stewart, M., \& Smith, D. (2003). Predicting academic performance and retention of private university freshmen in need of developmental education. Research \& Teaching in Developmental Education 19(2), 17-28.

Tinto, V. (1975). Dropout from higher education: a theoretical synthesis of recent research. Review of Educational Research 45, 89-125. http://dx.doi.org/10.3102/00346543045001089

Tross, S. A., Harper, J. P., Osher, L. W., \& Kneidinger, L. M. (2000). Not just the usual cast of characteristics: Using personality to predict college student performance and retention. Journal of College Student Development, 41(3), 323-334.

Van Houtte, M. (2004). Why boys achieve less at school than girls: The difference between boys' and girls' academic culture. Educational Studies 30, 159-173. http://dx.doi.org/10.1080/0305569032000159804

Wang, J., \& Goldschmidt, P. (2000). Opportunity to learn, language proficiency and immigrant status on mathematics achievement, The Journal of Educational Research $93 \quad$ (2), $101-111$. http://dx.doi.org/10.1080/00220679909597634

Washington, DC: National Center for Education Statistics, Institute of Education Sciences, U.S. Department of Education.

Waugh, G., Micceri, T., \& Takalkar, P. (1994). Using ethnicity, SAT/ACT scores, and high school GPA to predict retention and graduation rates (Report No. HE034024). Orlando, FL: Florida Association for Institutional Research.

Wilhite, P., Windham, B., \& Munday, R. (1998). Predictive effects of high school calculus and other variables on achievement in fist-semester college calculus course. College Student Journal 32 (4), 610-618.

Wolfe, R. N., \& Johnson S. D. (1995). Personality as a predictor of college performance. Educational and Psychological Measurement 55(2), 177-185. http://dx.doi.org/10.1177/0013164495055002002

Zheng, J. L., Saunders, K. P., Shelley II, M. C., \& Whalen, D. F. (2002). Predictors of academic success for freshmen residence hall students. Journal of College Student Development 43(2), 267-283. 